\title{
PENGARUH CORPORATE GOVERNANCE TERHADAP KINERJA INDUSTRI JASA NON KEUANGAN YANG TERDAFTAR DI BURSA EFEK INDONESIA
}

\author{
Farah Margaretha dan Evi Afriyanti \\ Dosen Fakultas Ekonomi \& Bisnis Universitas Trisakti \\ Email: farahmargaretha@gmail.com
}

\begin{abstract}
The aims of this research is analyze the effect ofcorporate governance to firm performance of non financial services industry listed in Indonesia Stock Exchange. The sample used as many 37 companies period 2010-2014. The dependent variable in this research is the firm performance is measured by Return on Assets (ROA), while the independent variable are ownership concentration, managerial ownership, board size, CEO family, agency costs (asset turnover and expense ratio), firm size and leverage (long term debt to total assets and long term debt to equity ratio). The analysis method used is multiple linear regression. The results show that there is a positive influence between the agency cost, firm size and leverage to firm performance, there is also negative influence between the agency costs and leverage to firm performance, and there is no influence between ownership concentration, managerial ownership, board size, CEO family to firm performance.
\end{abstract}

Keywords: Agency cost, board size, CEO family, firm performance, firm size, leverage, managerial ownership, and ownership concentration.

\begin{abstract}
Abstrak: Penelitian ini bertujuan untuk menganalisis pengaruh corporate governance terhadap kinerja industri jasa non keuangan yang terdaftar di Bursa Efek Indonesia (BEI). Sampel yang digunakan sebanyak 37 perusahaan dari tahun 2010-2014. Variabel dependen dalam penelitian ini adalah kinerja perusahaan yang diukur dengan Return on Asset (ROA), sedangkan variabel independennya adalah konsentrasi kepemilikan, kepemilikan manajerial, ukuran dewan direksi, CEO keluarga, biaya agensi, ukuran perusahaan. Metode analisis yang digunakan adalah regresi linier berganda. Hasil penelitian ini menunjukkan bahwa terdapat pengaruh positif antara biaya agensi (asset turnover), ukuran perusahaan dan leverage terhadap kinerja perusahaan, terdapat pengaruh negatif antara biaya agensi (expense ratio) dan leverage terhadap kinerja perusahaan, serta tidak ada pengaruh antara konsentrasi kepemilikan, kepemilikan manajerial,ukuran dewan direksi, dan CEO keluarga terhadap kinerja perusahaan.
\end{abstract}

Kata kunci: Biaya agensi, CEO keluarga, kinerja perusahaan, kepemilikan manajerial, konsentrasi kepemilikan, hutang, ukuran dewan direksi dan ukuran perusahaan.

\section{PENDAHULUAN}

Indonesia sebagai salah satu Negara yang jumlah penduduknya terbesar di dunia memiliki pertumbuhan ekonomi yang cukup baik di beberapa sektor usaha. Salah satu sektor usaha yang perkembangannya mengalami kemajuan pesat dari tahun ke tahun adalah usaha jasa (Margaretha dan Dhonna, 2011). Saat ini perhatian pemerintah juga sudah mulai 
berkembang di beberapa sektor usaha jasa terhadap kinerjanya. Karena salah satu tujuan utama dalam kegiatan bisnis untuk menghadapi persaingan global yang semakin ketat adalah bagaimana meningkatkan kinerja di suatu perusahaan (Al-Ghamdi dan Rhodes, 2015).

Kinerja perusahaan mencerminkan prestasi kerja dalam periode tertentu sehingga dapat digunakan untuk menentukan keberhasilan perusahaan dalam mencapai tujuannya. Memon et al. (2010) menyatakan kinerja adalah kualitas dari setiap perusahaan yang dapat dicapai dengan hasil yang membanggakan. Kinerja dapat diukur berdasarkan pengelolaan aset yang dimiliki agar menghasilkan keuntungan bagi perusahaan. Semakin baik kinerja perusahaan, maka keuntungan yang dihasilkan perusahaan semakin meningkat. Untuk mendapatkan keuntungan yang maksimal, terdapat banyak cara yang harus dilakukan oleh perusahaan, salah satu diantaranya yaitu dengan memiliki corporate governance yang baik.

Corporate governance merupakan tata kelola perusahaan yang menjelaskan hubungan antara berbagai partisipan dalam perusahaan yang menentukan arah dan kinerja perusahan (Darwis, 2009). Al-Ghamdi dan Rhodes (2015) menyatakan bahwa corporate governance adalah istilah yang sering digunakan untuk menjelaskan proses dan struktur yang digunakan untuk mengarahkan dan mengelola kegiatan usaha perusahaan dalam rangka meningkatkan kekayaan pemegang saham. Isu mengenai corporate governance ini mulai muncul di Indonesia setelah Indonesia mengalami masa krisis yang berkepanjangan sejak tahun 1998. Banyak pihak yang mengatakan lemahnya proses perbaikan di Indonesia disebabkan karena lemahnya corporate governance yang diterapkan di dalam perusahaan di Indonesia. Sejak saat itu, baik pemerintah maupun investor mulai memberikan perhatian yang cukup signifikan dalam praktek tata kelola perusahaan yang baik.

Disamping faktor tata kelola yang baik, faktor lain seperti konsentrasi kepemilikan saham (ownership concentration) juga dapat berpengaruh terhadap peningkatan kinerja disuatu perusahaan. Konsentrasi kepemilikan dapat berperan sebagai mekanisme corporate governance dalam mengurangi masalah keagenan. Masalah keagenan muncul karena pemisahan antara fungsi kepemilikan dan pengelola perusahaan. Penelitian AlGhamdi dan Rhodes (2015) menunjukan bahwa konsentrasi kepemilikan memiliki pengaruh positif signifikan terhadap kinerja perusahaan. Hastori et al. (2015) menyatakan dengan semakin terkonsentrasinya kepemilikan saham, maka pemilik saham yang besar dapat mempunyai insentif lebih untuk mengawasi kinerja para eksekutif, sehingga tindakan dan kebijakan para manajer yang tidak sejalan dengan tujuan perusahaan langsung dapat diketahui dan dicegah. Semakin besarnya kepemilikan saham dalam perusahaan, pemilik sekaligus pengendali mempunyai kepentingan yang lebih besar dalam mengamankan investasinya dalam perusahaan, sehingga sangat mungkin untuk melakukan pengawasan para manajemen dalam mengelola uangnya yang ditanamkan dalam perusahaan. Para pemilik perusahaaan pengendali akan lebih mudah mengganti para manajer yang dianggap kurang berhasil dalam mengelola investasinya.

Variabel yang digunakan untuk mengukur corporate governance dalam penelitian ini antara lain CEO family dan ukuran dewan direksi (board size). CEO family adalah CEO yang berasal dari keturunan keluarga pendiri dalam perusahaan keluarga di industri jasa. Al-Ghamdi dan Rhodes (2015) menemukan hubungan positif antara CEO family dengan kinerja perusahaan. Selain CEO, ukuran dewan direksi juga memiliki keterkaitan dengan kinerja perusahaan, karena dewan direksi merupakan mekanisme corporate governance yang penting untuk dapat memastikan bahwa manajer mengikuti aturan dewan 
direksi dan bekerja sesuai dengan kepentingan pemegang saham (Sari, 2015). Fama dan Jensen (1983) berpendapat jumlah maksimal anggota board size harus terdiri dari tujuh atau delapan anggota agar berfungsi secara efektif. Pendapat ini sesuai dengan penelitian (Al-Ghamdi dan Rhodes, 2015) yang menemukan hubungan positif antara ukuran dewan direksi dengan kinerja perusahaan, ketika ukuran dewan direksi meningkat maka kinerja perusahaan juga akan meningkat. Namun, berbeda dengan pendapat (Sari, 2015) yang menyatakan bahwa perusahaan menjadi kurang efektif jika memiliki dewan direksi dalam jumlah yang besar karena dapat menyebabkan permasalahan agensi. Masalah agensi muncul karena pemisahan kepentingan antara pemegang saham dan pengelola perusahaan yang menimbulkan konflik kepentingan. Dimana pemegang saham ingin memaksimalkan harga saham dan return yang tinggi dari investasinya, tetapi manajer memiliki kebutuhan yang lebih luas, salah satunya memaksimalkan kompensasi dan gaji yang akan diterimanya nanti (Setyapurnama dan Norpratiwi, 2006). Konflik kepentingan muncul ketika manajer tidak selalu bertindak seperti yang diinginkan oleh pemegang saham sebagai pemilik modal yang menghendaki bertambahnya kekayaan dan kemakmuran, namun disisi lain pihak manajer menginginkan bertambahnya kesejahteraan bagi mereka, karena adanya permasalahan yang sering terjadi maka akan memicu biaya agensi (Sari, 2015). Jensen dan Meckling (1976) mendefinisikan biaya agensi sebagai jumlah dari biaya yang dikeluarkan pemegang saham untuk melakukan pengawasan terhadap manajer.

Biaya agensi dapat dikurangi dengan kepemilikan manajerial (managerial ownership) yang tinggi, kepemilikan manajerial yang tinggi dapat membantu menyelaraskan kepentingan pemegang saham dan manajer (Jensen, 1993). Dengan memberikan hak kepemilikan atas perusahaan dalam bentuk saham kepada manajer sebagai bentuk penghargaan atas kinerja manajer, maka manajer akan bertindak secara hati-hati karena mereka ikut menanggung konsekuensi atas keputusan yang diambilnya. Selain itu dengan adanya keterlibatan kepemilikan saham, manajer akan termotivasi untuk meningkatkan kinerjanya dalam mengelola perusahaan.

Penerapan corporage governance dalam perusahaan diharapkan dapat membawa perubahan yang lebih baik dengan meningkatkan pengawasan terhadap manajemen dengan mendorong pengambilan keputusan yang efektif salah satunya besarnya biaya hutang. Ukuran perusahaan yang besar juga berpengaruh terhadap kemudahan perusahaan dalam memperoleh hutang. Penelitian Izati dan Margaretha (2014) menunjukkan bahwa leverage berpengaruh negatif terhadap kinerja perusahaan. Karena besarnya hutang yang diambil mengakibatkan perusahaan menanggung beban bunga yang semakin besar pula yang berdampak terhadap pengurangan profit perusahaan dikarenakan banyaknya kas perusahaan yang digunakan untuk membayar biaya hutang sehingga dapat berpengaruh terhadap penurunan kinerja perusahaan.

Penelitian ini bertujuan untuk mengetahui faktor-faktor dalam corporate governance (ownership concentration, managerial ownership, board size, CEO family, dan agency cost,) yang mempengaruhi kinerja perusahan.

\section{KAJAIN TEORI}

Kinerja perusahaan (firm performance) adalah pengukuran prestasi yang telah dicapai oleh perusahaan yang menunjukkan kondisi yang baik untuk jangka waktu tertentu. Tujuan dari pengukuran prestasi tersebut untuk mendapatkan informasi yang berguna terkait dengan aliran dana, penggunaan dana, efektivitas, dan efisiensi. Kinerja 
adalah kualitas dari setiap perusahaan yang dapat dicapai dengan hasil yang membanggakan (Memon et al. 2010). Menurut Al-Ghamdi dan Rhodes (2015) kinerja perusahaan merupakan hasil akhir prestasi kerja yang dicapai oleh suatu perusahaan atas target atau standar yang telah ditetapkan pada setiap awal periode. Menurut Hastori et al. (2015) penilaian kinerja perusahaan merupakan upaya untuk menilai keberhasilan atau melihat seberapa baik aktifitas suatu perusahaan yang telah dilakukan sepanjang tahun. Penilaian kinerja bermanfaat sebagai bahan monitoring dan evaluasi yang selanjutnya untuk mengidentifikasi masukan- masukan (feedback) untuk melakukan perbaikanperbaikan (improvement) yang diperlukan secara bersinambungan. Manfaat lain dari penilaian kinerja selain sebagai alat evaluasi bagi manajemen maupun dan pemangku kepentingan lain, hasil penilaian kinerja juga dapat digunakan sebagai alat untuk menentukan sistem imbalan kerja yang wajar. Semakin baik kinerja perusahaan, maka keuntungan yang dihasilkan perusahaan semakin meningkat. Kinerja perusahaan merupakan hal penting yang harus dicapai oleh setiap perusahaan yang merupakan cerminan dari tingkat keberhasilan manajemen dalam mengelola sumberdaya keuangan perusahaan, terutama pada pengelolaan investasi sebagai upaya untuk menciptakan nilai bagi pemegang saham (Sari dan Usman, 2014). Gitman dan Zutter (2015) menyatakan bahwa kinerja perusahaan umumnya diukur melalui profitabilitas dari suatu laporan keuangan perusahaan. Semakin tinggi profit yang dihasilkan, maka semakin tinggi penilaian terhadap kinerja perusahaan, profitabilitas dapat menunjukkan kinerja perusahaan yang baik. Profitabilitas merupakan faktor penting dalam manajemen keuangan karena salah satu tujuan manajemen keuangan ialah memaksimalkan kesejahteraan pemegang saham. Salah satu rasio profitabilitas yang sering digunakan untuk mengukur kinerja perusahaan yaitu Return on asset (ROA). Return on asset digunakan untuk mengukur keefektifan manajemen dalam menghasilkan laba dengan aset yang tersedia, semakin tinggi pengembalian perusahaan atas total aset semakin baik kinerja perusahaan (Gitman dan Zutter, 2015).

Corporate governance merupakan tata kelola perusahaan menjelaskan hubungan antara berbagai partisipan dalam perusahaan yang menentukan arah dan kinerja perusahan (Darwis, 2009). Al-Ghamdi dan Rhodes (2015) menyatakan bahwa corporate governance adalah istilah yang sering digunakan untuk menjelaskan proses dan struktur yang digunakan untuk mengarahkan dan mengelola kegiatan usaha perusahaan dalam rangka meningkatkan kekayaan pemegang saham. Menurut Hastori et al. (2015) corporate governance adalah prinsip yang mengarahkan dan mengendalikan perusahaan agar mencapai keseimbangan antara kekuatan serta kewenangan perusahaan dalam memberikan pertanggung jawabannya kepada para shareholder khususnya, dan stakeholder pada umumnya. Tentu saja hal ini dimaksudkan pengaturan kewenangan dewan direksi, manajer, pemegang saham, dan pihak lainnya yang berhubungan dengan perkembangan perusahaan di lingkungan tertentu. Corporate governance sangat berkaitan dengan bagaimana membuat para investor yakin bahwa manajer akan memberikan keuntungan bagi mereka dengan tidak menggelapkan atau menginvestasikan modal yang telah ditanamkan oleh investor ke dalam proyek-proyek yang tidak menguntungkan. Menurut Forum for Corporate Governance in Indonesia (FCGI, 2006) pengertian corporate governance adalah seperangkat peraturan yang mengatur hubungan antara pemegang saham, pengurus (pengelola) perusahaan, pihak kreditur, pemerintah, karyawan serta para pemegang kepentingan intern dan esktern lainnya yang berkaitan dengan hakhak dan kewajiban mereka atau dengan kata lain suatu sistem yang mengatur dan 
mengendalikan perusahaan. Tujuan dari tata kelola perusahaan adalah untuk menciptakannilai tambah bagi stakeholders.

Wright et al. (2009) juga menemukan bahwa agency cost berpengaruh negatif dan signifikan terhadap kinerja perusahaan, artinya bila agency cost dibiarkan membengkak, maka hal tersebut dapat mengurangi pencapaian keuntungan kompetitif yang berdampak negatif terhadap kinerja. Miyajima et al. (2008) menemukan pengaruh positif dari ukuran perusahaan terhadap kinerja perusahaan. perusahaan akan memperoleh keuntungan yang besar, semakin besarnya keuntungan maka kinerja di perusahaan akan semakin meningkat. Al-Ghamdi dan Rhodes (2015) menyatakan bahwa leverage memiliki pengaruh yang negatif terhadap kinerja, karena jika terlalu banyak hutang dapat meningkatkan risiko kebangkrutan dan membatasi kemampuan perusahaan untuk meningkatkan modal baru.

Pengembangan Hipotesis. Ehikioya (2009) yang menyatakan bahwa adanya kepemilikan yang terkonsentrasi baik di tangan individu, perusahaan maupun institusional akan menciptakan insentif yang lebih baik bagi para pemegang saham untuk melakukan proses monitoring sehingga berdampak pada kinerja yang lebih baik. Al-Ghamdi dan Rhodes (2015) menunjukan bahwa konsentrasi kepemilikan memiliki pengaruh positif signifikan terhadap kinerja perusahaan. Penelitian ini sesuai dengan penelitian yang dilakukan oleh Shleifer dan Vishny (2006) yang menemukan hubungan positif antara konsentrasi kepemilikan terhadap kinerja perusahaan. Kepemilikan terkonsentrasi dapat berperan sebagai mekanisme corporate governance dalam mengurangi persoalan keagenan, sebab konsentrasi kepemilikan dapat menjadikan pemegang saham pada posisi yang kuat untuk dapat mengendalikan manajemen secara efektif mengawasi manajer dengan lebih baik, sehingga mendorong manajemen bertindak sesuai dengan kepentingan pemegang saham. Berbeda dengan penelitian Demsetz (2013) yang menemukan bahwa tidak ada hubungan antara konsentrasi dengan peningkatan kinerja perusahaan. Dari pembahasan tersebut, hipotesis yang diusulkan:

H1: Terdapat pengaruh antara Ownership Concentration terhadap Firm Performance

Managerial ownership adalah situasi dimana manajer memiliki saham perusahaan atau dengan kata lain manajer tersebut sekaligus sebagai pemegang saham perusahaan. Kepemilikan ini merupakan konsekuensi adanya kompensasi kepemilkan saham yang diberikan oleh perusahaan kepada manajemen. Menurut Wahidahwati (2012), kepemilikan manajerial merupakan pemegang saham dari pihak manajemen yang secara aktif ikut dalam pengambilan keputusan perusahaan, yakni direksi dan komisaris. Struktur kepemilikan saham manajerial diukur sebagai persentase saham yang dimiliki oleh Board of Management yang didalamnya terdapat direksi dan komisaris. Morck et al. (1988) menemukan hubungan yang positif signifikan antara kepemilikan manajerial dan kinerja perusahaan. Jensen dan Meckling (1976) juga berpendapat bahwa terdapat hubungan positif antara peningkatan kepemilikan manajerial terhadap kinerja perusahaan. Kepemilikan manajerial dipandang dapat menyelaraskan potensi perbedaan kepentingan antara pemegang saham dan manajer sehingga permasalahan keagenan diasumsikan akan hilang apabila seorang manajer juga sebagai seorang pemilik. Selain itu, kepemilikan manajerial yang lebih tinggi dapat mengurangi biaya keagenan sehingga hal ini berpengaruh pada semakin baik dan meningkatnya kinerja perusahaan (Jensen dan Meckling, 1976). Hal ini sesuai dengan penelitian Al-Ghamdi dan Rhodes (2015) yang menyatakan bahwa kepemilikan manajerial memiliki pengaruh positif signifikan terhadap kinerja perusahaan. Semakin besar proporsi kepemilikan manajerial, maka manajer akan 
termotivasi untuk meningkatkan kinerjanya sehingga akan berdampak baik bagi kesejahteraan perusahaan serta memenuhi keinginan dari para pemegang saham. Dari pembahasan tersebut, hipotesis yang diusulkan:

$\mathbf{H}_{2}$ : Terdapat pengaruh antara Managerial Ownership terhadap Firm Performance

Fama dan Jensen (1983) berpendapat jumlah maksimal anggota board size harus terdiri dari tujuh atau delapan anggota agar berfungsi secara efektif. Al-Ghamdi dan Rhodes (2015) menemukan hubungan positif antara ukuran dewan direksi dengan kinerja perusahaan, ketika ukuran dewan direksi meningkat maka kinerja perusahaan juga akan meningkat. Bertambahnya jumlah dewan direksi dapat memberikan ide-ide bisnis bagi perusahaan sehingga dapat menyebabkan perubahan yang dapat meningkatkan kinerja perusahaan. Coles et al. (2008) dalam penelitiannya menyatakan bahwa ukuran dewan direktur berpengaruh positif terhadap kinerja perusahaan, dimana dewan yang lebih besar menyediakan pemantauan yang lebih besar sehingga dapat meningkatkan kinerja perusahaan.

Namun, berbeda dengan penelitian yang dilakukan Lipton dan Lorsch (2012) menyatakan bahwa terdapat perngaruh yang negatif dalam besarnya ukuran dewan direksi. Yermack (2006) juga menemukan bahwa ukuran dewan direksi berpengaruh negatif terhadap kinerja perusahaan, dimana akan ada tambahan biaya yang muncul akibat penambahan jumlah anggota dewan direksi. Dari pembahasan tersebut, hipotesis yang diusulkan:

H3: Terdapat pengaruh antara Board Size terhadap Firm Performance

CEO family menggambarkan bahwa perusahaan tersebut adalah perusahaan keluarga, dimana posisi penting dipegang oleh anggota keluarga. Al-Ghamdi dan Rhodes (2015) menemukan hubungan positif antara CEO family dengan kinerja perusahaan. Barberis et al. (1996) menyatakan bahwa kompetensi CEO merupakan faktor yang sangat penting dalam peningkatan profitabilitas perusahaan. Dengan meningkatnya profitabilitas, maka akan meningkatkan kinerja pada perusahaan tersebut. Menurut Athanassiou et al. (2012) menyatakan bahwa CEO family berpengaruh positif terhadap profitabilitas perusahaan dan nilai perusahaan, karena perusahaan keluarga memiliki rasa kepemilikan dan kepedulian yang tinggi terhadap reputasi perusahaannya. Namun berbeda dari hasil penelitian Sindhuja (2009) yang menunjukkan bahwa CEO family berpengaruh negatif terhadap profitabilitas perusahaan dan nilai perusahaan. Perusahaan keluarga seringkali mempertahankan pemimpin yang sudah tidak kompeten lagi yang dapat menghambat perekrutan manajemen yang lebih kompeten dan profesional, sehingga dapat mempengaruhi penurunan kinerja disuatu perusahaan. Dari pembahasan tersebut, hipotesis yang diusulkan:

H4: Terdapat pengaruh antara CEO Family terhadap Firm Performance

Al-Ghamdi dan Rhodes (2015) menyatakan bahwa biaya agensi memiliki pengaruh yang negatif terhadap kinerja perusahaan. Wright et al. (2009) juga menemukan bahwa agency cost berpengaruh negatif dan signifikan terhadap kinerja perusahaan, artinya bila agency cost dibiarkan membengkak, maka hal tersebut dapat mengurangi pencapaian keuntungan kompetitif yang berdampak negatif terhadap kinerja.

Jensen dan Meckling (1976) mengemukakan bahwa agency cost akan rendah jika kepemilikan manajerial tinggi. Hal ini dapat terjadi karena kepemilikan saham manajerial memungkinkan adanya penyatuan kepentingan antara manajer dan pemegang saham, yang berarti makin tingginya proporsi kepemilikan saham manajerial maka manajemen akan berupaya lebih giat untuk memenuhi kepentingan pemegang saham dan juga dirinya 
sendiri. Dengan demikian, meningkatnya kepemilikan saham manajerial akan meminimumkan biaya agensi yang merupakan insentif bagi para manajer untuk meningkatkan kinerja perusahaan. Dari pembahasan tersebut, hipotesis yang diusulkan:

H5: Terdapat pengaruh antara Agency Cost terhadap Firm Performance

Penelitian Miyajima et al. (2008) menemukan pengaruh positif dari ukuran perusahaan terhadap kinerja perusahaan. Perusahaan besar dengan akses pasar yang lebih baik mempunyai aktivitas operasional yang lebih luas sehingga mempunyai kemungkinan untuk mendapatkan keuntungan lebih besar yang dapat meningkatkan kinerja perusahaan, sehingga antara ukuran perusahaan dan kinerja perusahaan memiliki pengaruh yang positif. Wright et al. (2009) juga menemukan bahwa ukuran perusahaan berpengaruh positif terhadap kinerja. Namun, berbeda dengan penelitian Al-Ghamdi dan Rhodes (2015) yang tidak menemukan pengaruh antara ukuran perusahaan dengan kinerjanya. Hal ini menunjukkan bahwa ukuran perusahaan bukan jaminan bahwa perusahaan akan memiliki kinerja yang baik. Dari pembahasan tersebut, hipotesis yang diusulkan:

H6: Terdapat pengaruh antara Firm Size terhadap Firm Performance

Penelitian Izati dan Margaretha (2014) menunjukan bahwa leverage berpengaruh negatif terhadap kinerja perusahaan. Besarnya hutang mengakibatkan perusahaan menanggung beban bunga yang semakin besar pula yang berdampak terhadap pengurangan profit perusahaan dikarenakan banyaknya kas perusahaan yang digunakan untuk membayar biaya hutang sehingga dapat berpengaruh terhadap penurunan kinerja perusahaan. Al-Ghamdi dan Rhodes (2015) menyatakan bahwa leverage memiliki pengaruh yang negatif terhadap kinerja, karena jika terlalu banyak hutang dapat meningkatkan risiko kebangkrutan dan membatasi kemampuan perusahaan untuk meningkatkan modal baru. Berbeda dengan penelitian yang dilakukan Jensen (1986) menemukan bahwa leverage mencerminkan hubungan positif bagi nilai dan kinerja perusahaan. Perusahaan yang melakukan leverage mampu meyakinkan kreditur untuk memperoleh cash flows yang dapat digunakan untuk membayar biaya-biaya operasional perusahaan. Dari pembahasan tersebut, hipotesis yang diusulkan:

H7: Terdapat pengaruh antara Leverage terhadap Firm Performance

\section{METODE}

Metode yang digunakan untuk memperoleh sampel dalam penelitian ini adalah dengan menggunakan purposive sampling method, dengan kriteria sebagai berikut: (1) Perusahaan yang diteliti hanya perusahaan jasa non keuangan yang terdaftar di Bursa Efek Indonesia untuk periode penelitian 2010-2014; (2) Selama periode penelitian perusahaan harus tetap listing di Bursa Efek Indonesia; (3) Perusahaan tersebut mempunyai data laporan keuangan yang lengkap dari tahun 2010-2014; (4) Memiliki data kepemilikan manajerial; (5) Mata uang yang digunakan perusahaan dalam bentuk nilai rupiah (IDR).

Metode analisis yang digunakan dalam penelitian ini adalah analisis regresi linier berganda. Persamaan regresi berganda yang digunakan adalah sebagai berikut :

ROA

$$
\begin{aligned}
= & \beta_{0}+\beta_{1} \mathrm{OC}+\beta_{2} \mathrm{MO}+\beta_{3} \mathrm{BS}+\beta_{4} \mathrm{CEOFAM}+\beta_{5} \mathrm{AGCOST}_{1}+ \\
& \beta_{6} \mathrm{AGCOST}_{2}+\beta_{7} \mathrm{FS}+\beta_{8} \mathrm{LEV}_{1}+\beta_{9} \mathrm{LEV}_{2}+\mathrm{e}
\end{aligned}
$$

Dimana: $\mathrm{ROA}=$ Firm Performance $; \mathrm{OC}=$ Ownership Concentration $; \mathrm{MO}=$ Managerial Ownership; $\mathrm{BS}=$ Board Size $; \mathrm{CEOFAM}=$ CEO Family; AGCOST $_{1}=$ Agency Cost (Asset 
Turnover); AGCOST $_{2}=$ Agency Cost (Expense Ratio); FS = Firm Size $; \mathrm{LEV}_{1}=$ Leverage (Long term debt to total asset) $\mathrm{LEV}_{2}=$ Leverage (Long term debt to equity ratio); $\mathrm{e}=$ Error

Uji t (Uji Individu). Uji ini dilakukan untuk menguji apakah masing-masing variabel independen mempunyai pengaruh yang signifikan terhadap variabel dependennya dengan mengasumsikan variabel lain adalah konstan. Berikut ini hipotesis dari uji t:

Ho: Variabel independen tidak mempengaruhi variabel dependen.

Ha: Variabel independen mempengaruhi variabel dependen.

Adapun kriteria keputusannya:

a. Jika sig. $t$ statistik $<0,05$ maka Ho ditolak

b. Jikasig. t statistik $>0,05$ maka Ho diterima.

Tabel 1. Variabel dan Pengukuran

\begin{tabular}{|c|c|c|c|}
\hline Variabel & Indikator & Alat Ukur & Sumber \\
\hline $\begin{array}{l}\text { Dependen : } \\
\quad \text { Firm } \\
\text { performance }\end{array}$ & $\begin{array}{c}\text { Return on } \\
\text { Asset (ROA) }\end{array}$ & $\frac{\text { Net income }}{\text { Total asset }}$ & $\begin{array}{l}\text { Al-Ghamdi dan } \\
\text { Rhodes, } 2015\end{array}$ \\
\hline \multirow[t]{9}{*}{ Independen: } & $\begin{array}{l}\text { Ownership } \\
\text { concentration }\end{array}$ & $\begin{array}{l}\text { Persentase dari total saham beredar yang } \\
\text { dimiliki oleh pemegang saham terbesar yang } \\
\text { memiliki lebih dari } 10 \% \text { saham perusahaan }\end{array}$ & $\begin{array}{l}\text { Al-Ghamdi dan } \\
\text { Rhodes, } 2015\end{array}$ \\
\hline & $\begin{array}{l}\text { Managerial } \\
\text { ownership }\end{array}$ & $\begin{array}{l}\text { Presentase kepemilikan saham yang dimiliki } \\
\text { oleh pihak manajemen }\end{array}$ & $\begin{array}{l}\text { Wahidahwati, } \\
2012\end{array}$ \\
\hline & Board size & Jumlah dewan direksi dalam suatu perusahaan & $\begin{array}{l}\text { Al-Ghamdi dan } \\
\text { Rhodes, } 2015\end{array}$ \\
\hline & CEO family & $\begin{array}{l}\text { Variabel dummy, } 1 \text { jika posisi CEO di } \\
\text { perusahaan dipegang oleh anggota keluarga dan } \\
0 \text { jika bukan anggota keluarga. }\end{array}$ & $\begin{array}{l}\text { Al-Ghamdi dan } \\
\text { Rhodes, } 2015\end{array}$ \\
\hline & \multirow[t]{2}{*}{ Agency cost } & Assets turnover $=\frac{\text { Sales }}{\text { Total assets }}$ & \multirow[t]{2}{*}{$\begin{array}{l}\text { Al-Ghamdi dan } \\
\text { Rhodes, } 2015\end{array}$} \\
\hline & & Expense ratio $=\frac{\text { Operating expense }}{\text { Sales }}$ & \\
\hline & Firm size & Logarithm of total asset & $\begin{array}{l}\text { Al-Ghamdi dan } \\
\text { Rhodes, } 2015\end{array}$ \\
\hline & \multirow[t]{2}{*}{ Leverage } & LTDTA $=\frac{\text { Long term debt }}{\text { Total assets }}$ & \multirow[t]{2}{*}{$\begin{array}{l}\text { Al-Ghamdi dan } \\
\text { Rhodes, } 2015\end{array}$} \\
\hline & & LTDTE $=\frac{\text { Long term debt }}{\text { Total equity }}$ & \\
\hline
\end{tabular}

\section{HASIL DAN PEMBAHASAN}

Variabel yang digunakan dalam penelitian ini adalah ownership concentration, managerial ownership, board size, CEO family, agency cost, firm size, dan leverage terhadap firm performance yang diukur oleh return on asset. Berikut ini adalah hasil statistik deskriptif dari data yang digunakan dalam penelitian ini. 
Tabel 2. Statistik Deskriptif

\begin{tabular}{|c|c|c|c|c|c|}
\hline Variabel & $\mathrm{N}$ & Minimum & Maximum & Mean & Std. Deviasi \\
\hline Return on Asset (ROA) & 185 & $-0,1026$ & 0,1651 & 0,0390 & 0,04661 \\
\hline Ownership Concentration & 185 & 0,1842 & 0,9400 & 0,6582 & 0,18579 \\
\hline Managerial Ownership & 185 & 0,0000 & 0,9561 & 0,0671 & 0,14655 \\
\hline Board Size & 185 & 2 & 9 & 4,57 & 1,686 \\
\hline CEO Family & 185 & 0 & 1 & 0,49 & 0,501 \\
\hline Asset Turnover & 185 & 0,0135 & 4,1830 & 0,4964 & 0,59994 \\
\hline Expense Ratio & 185 & 0,0141 & 4,4564 & 0,2990 & 0,46528 \\
\hline Firm Size & 185 & 10,466 & 14,149 & 12,149 & 0,83034 \\
\hline $\begin{array}{l}\text { Long Term Debt to Total } \\
\text { Asset }\end{array}$ & 185 & 0,0000 & 0,6599 & 0,2160 & 0,15512 \\
\hline $\begin{array}{l}\text { Long Term Debt to Equity } \\
\text { Ratio }\end{array}$ & 185 & 0,0000 & 3,0022 & 0,5596 & 0,62544 \\
\hline
\end{tabular}

Ownership Concentration. Berdasarkan tabel 3 diketahui nilai signifikansi ownership concentration yaitu sebesar $0,113>0,05$. Artinya, tidak terdapat pengaruh antara ownership concentration terhadap firm performance. Hasil penelitian ini tidak sesuai dengan penelitian yang dilakukan olehAl-Ghamdi dan Rhodes (2015) yang menunjukan bahwa konsentrasi kepemilikan memiliki pengaruh positif signifikan terhadap kinerja perusahaan. Hasil penelitian ini juga tidak sesuai dengan penelitian Shleifer dan Vishny (1986) yang menemukan hubungan positif antara konsentrasi kepemilikan terhadap kinerja perusahaan, dimana kepemilikan terkonsentrasi dapat menjadikan pemegang saham pada posisi yang kuat untuk dapat mengendalikan manajemen secara efektif mengawasi manajer dengan lebih baik, sehingga mendorong manajemen bertindak sesuai dengan kepentingan pemegang saham.

Tetapi hasil penelitian ini sesuai dengan penelitian Demsetz (1983) yang menemukan bahwa tidak ada hubungan antara konsentrasi dengan peningkatan kinerja perusahaan. Hal ini menunjukan bahwa pemegang saham yang terkonsentrasi bukan merupakan faktor utama yang dapat mempengaruhi kinerja perusahaan, karena pemegang saham tidak ikut secara langsung dalam kegiatan operasional diperusahaan, tetapi yang berperan penting untuk dapat meningkatkan kinerja di perusahaan adalah para manajernya, bagaimana manajer yang ada diperusahaan tersebut dapat mengelola perusahaannya dengan baik sehingga dapat meningkatkan profitabilitas perusahaan. Semakin meningkatnya profitabilitas, maka keuntungan yang diperoleh akan lebih besar, dari keuntungan tersebut dapat membuat manajer maupun karyawan akan termotivasi untuk terus meningkatkan kinerjanya.

Managerial Ownership. Berdasarkan tabel 3 diketahui nilai signifikansi managerial ownership yaitu sebesar $0,251>0,05$. Artinya, tidak terdapat pengaruh antara managerial ownership terhadap firm performance. Hasil penelitian ini tidak sesuai dengan penelitian yang dilakukan oleh Al-Ghamdi dan Rhodes (2015) yang menemukan bahwa kepemilikan manajerial memiliki pengaruh positif signifikan terhadap kinerja perusahaan, semakin 
besar proporsi kepemilikan manajerial, maka manajer akan termotivasi untuk meningkatkan kinerjanya sehingga akan berdampak baik bagi kesejahteraan perusahaan serta memenuhi keinginan dari para pemegang saham.

Namun, hasil penelitian ini sesuai dengan penelitian yang dilakukan oleh Darwis (2009) yang menyatakan tidak berpengaruhnya kepemilikan manajerial terhadap kinerja perusahaan, hal ini disebabkan karena kepemilikan saham oleh manajer masih sangat kecil maka manajer belum merasakan manfaat dari kepemilikan tersebut sehingga kemungkinan manajer akan bertindak untuk kepentingan dirinya sendiri.

Tabel 3. Hasil Uji t

\begin{tabular}{lccc}
\hline \multicolumn{1}{c}{ Variabel } & Koefisien & Sig. & Kesimpulan \\
\hline Constant & $-19,347$ & 0,001 & \\
Ownership Concentration & 2,849 & 0,113 & Tidak Signifikan \\
Managerial Ownership & $-2,481$ & 0,251 & Tidak Signifikan \\
Board Size & 0,308 & 0,165 & Tidak Signifikan \\
CEO Family & 0,647 & 0,306 & Tidak Signifikan \\
Asset Turnover & 1,758 & 0,001 & Signifikan \\
Expense Ratio & $-2,120$ & 0,002 & Signifikan \\
Firm Size & 1,614 & 0,001 & Signifikan \\
Long Term Debt to Total Asset & 9,370 & 0,045 & Signifikan \\
Long Term Debt to Equity Ratio & $-3,725$ & 0,001 & Signifikan \\
\hline
\end{tabular}

Board Size. Berdasarkan Tabel 3 diketahui nilai signifikansi board size yaitu sebesar $0,165>0,05$. Artinya, tidak terdapat pengaruh antara board size terhadap firm performance. Hasil penelitian ini tidak sesuai dengan penelitian yang dilakukan oleh AlGhamdi dan Rhodes (2015) menemukan hubungan positif antara ukuran dewan direksi dengan kinerja perusahaan, ketika ukuran dewan direksi meningkat maka kinerja perusahaan juga akan meningkat. Hasil penelitian ini juga tidak sesuai dengan penelitian Coles et al. (2008) yang menyatakan bahwa ukuran dewan direksi berpengaruh positif terhadap kinerja perusahaan, dimana dewan yang lebih besar menyediakan pemantauan yang lebih besar sehingga meningkatkan dapat kinerja perusahaan.

Tetapi, hasil penelitian ini sesuai dengan penelitian Wulandari (2006) yang menunjukan bahwa jumlah dewan direksi tidak berpengaruh terhadap kinerja perusahaan. Jumlah dewan direksi yang optimal tergantung masing-masing perusahaan. Hal ini menunjukkan bahwa untuk dapat meningkatkan kinerja di perusahaan jasa bukan dilihat dari besar kecilnya jumlah dewan direksi, akan tetapi bagaimana dewan direksi yang sudah ada diperusahaan tersebut dapat bekerja secara efektif dalam menjalankan tanggung jawabnya untuk mengelola perusahaan sesuai dengan peraturan yang berlaku. Sehingga dapat disimpulkan bahwa besar kecilnya dewan direksi bukanlah menjadi faktor penentu utama meningkatkan kinerja di dalam perusahaan.

CEO Family. Berdasarkan Tabel 3 diketahui nilai signifikansi CEO family yaitu sebesar $0,306>0,05$. Artinya, tidak terdapat pengaruh antara CEO family terhadap firm performance. Hasil penelitian ini tidak sesuai dengan penelitian yang dilakukan oleh AlGhamdi dan Rhodes (2015) yang menemukan hubungan positif antara CEO family dengan kinerja perusahaan. Hasil penelitian ini juga tidak sesuai dengan penelitian Barberis et al. (1996) menyatakan bahwa kompetensi CEO merupakan faktor yang sangat penting dalam peningkatan profitabilitas perusahaan, dimana dengan meningkatnya profitabilitas, maka 
akan meningkatkan kinerja pada perusahaan tersebut. Hal ini membuktikan bahwa dengan adanya CEO dari perusahaan keluarga tidak menjamin bahwa kinerja diperusahaan tersebut dapat meningkat. Selain itu para investor yang ingin menanamkan modalnya di Indonesia pun cenderung tidak mempermasalahkan apakah perusahaan tersebut merupakan perusahaan keluarga atau bukan.

Agency Cost. Berdasarkan Tabel 3 diketahui nilai signifikansi agency cost (asset turnover yaitu sebesar 0,001 $<0,05$ dengan koefisien regresi sebesar 1,758. Artinya, agency cost (asset turnover) berpengaruh positif signifikan terhadap firm performance. Hasil penelitian ini bertolak belakang dengan penelitian yang dilakukan oleh Al-Ghamdi dan Rhodes (2015) menyatakan bahwa biaya agensi memiliki pengaruh yang negatif terhadap kinerja perusahaan. Hal ini disebabkan karena rasio asset turnover digunakan untuk mengukur efektivitas manajemen perusahaan dalam menggunakan asetnya untuk menciptakan penjualan dan mendapatkan keuntungan. Jadi semakin tinggi biaya agensi disuatu perusahaan maka semakin efektif manajemen dalam mengelola perusahaannya yang dapat memperoleh keuntungan yang besar dari hasil penjulannya, sehingga dapat meningkatkan kinerja pada perusahaan jasa tersebut.

Hasil penelitian selanjutnya menunjukkan nilai signifikansi agency cost (expense ratio) yaitu sebesar 0,002<0,05 dengan koefisien regresi sebesar -2,120. Artinya, agency cost (expense ratio) berpengaruh negatif signifikan terhadap firm performance. Hasil penelitian ini sesuai dengan penelitian Al-Ghamdi dan Rhodes (2015) dan Wright et al. (2009) yang menemukan bahwa agency cost berpengaruh negatif dan signifikan terhadap kinerja perusahaan, artinya bila agency cost dibiarkan membengkak, maka hal tersebut dapat mengurangi pencapaian keuntungan kompetitif yang berdampak negatif terhadap kinerja. Karena semakin tinggi rasio beban ini maka semakin tinggi biaya agensinya, hal ini menandakan bahwa pihak manajerial tidak efisien dalam mengontrol biaya-biaya operasional perusahaan yang dapat menurunkan kinerja diperusahaan jasa tersebut.

Firm Size. Berdasarkan Tabel 3 diketahui nilai signifikansi firm size yaitu sebesar 0,001 < 0,05 dengan koefisien regresi sebesar 1,614. Artinya, firm size berpengaruh positif signifikan terhadap firm performance. Hasil penelitian ini sejalan dengan penelitian yang dilakukan oleh Coles et al. (2008) dan Miyajima et al. (2003) yang menemukan pengaruh positif dari ukuran perusahaan terhadap kinerja perusahaan. Perusahaan besar memiliki akses pasar yang lebih baik mempunyai aktivitas operasional yang lebih luas sehingga mempunyai kemungkinan untuk mendapatkan keuntungan lebih besar dengan mengelola aset yang tersedia dengan bijak dan perencanaan yang matang, perusahaan akan memperoleh keuntungan yang besar, semakin besarnya keuntungan maka kinerja di perusahaan akan semakin meningkat.

Leverage. Berdasarkan Tabel 3 diketahui nilai signifikansi leverage (long term debt to total asset) yaitu sebesar 0,045 < 0,05 dengan koefisien regresi sebesar 9,370. Artinya, leverage (long term debt to total asset) berpengaruh positif signifikan terhadap firm performance. Hasil penelitian ini sesuai dengan penelitian yang dilakukan oleh Jensen (1986) menyatakan bahwa leverage mencerminkan hubungan positif dari nilai perusahaan. Perusahaan yang melakukan leverage mampu meyakinkan kreditur untuk memperoleh cash flows yang dapat digunakan dalam membayar biaya-biaya operasional perusahaan. Selain itu, leverage yang tinggi juga dapat mengurangi beban pajak perusahaan, sehingga 
tingkat return investasi yang diberikan kepada investor akan lebih besar, hal tersebut dapat meningkatkan nilai dan kinerja perusahaan.

Hasil penelitian selanjutnya menunjukkan nilai signifikansi leverage (long term debt to equity ratio) yaitu sebesar 0, $001<0,05$ dengan koefisien regresi sebesar -3,725. Artinya, leverage (long term debt to equity ratio) berpengaruh negatif signifikan terhadap firm performance. Hasil penelitian ini sesuai dengan penelitian yang dilakukan oleh AlGhamdi dan Rhodes (2015) yang menyatakan bahwa leverage memiliki pengaruh yang negatif terhadap kinerja, karena jika terlalu banyak hutang dapat meningkatkan risiko kebangkrutan dan membatasi kemampuan perusahaan untuk meningkatkan modal baru. Hasil penelitian ini juga didukung dengan penelitian yang dilakukan oleh Izati dan Margaretha (2014) yang menunjukan bahwa leverage berpengaruh negatif terhadap kinerja perusahaan. Besarnya hutang mengakibatkan perusahaan menanggung beban bunga yang semakin besar pula, yang berdampak terhadap pengurangan profit perusahaan dikarenakan banyaknya kas perusahaan yang digunakan untuk membayar biayahutang sehingga dapat berpengaruh terhadap penurunan kinerja perusahaan.

\section{PENUTUP}

Simpulan. Berdasarkan hasil penelitian yang menganalisa pengaruh ownership concentration, managerial ownership, board size, CEO family, agency cost, firm size dan leverage terhadap firm performance pada perusahaan jasa yang terdaftar di Bursa Efek Indonesia selama periode 2010-2014, maka dapat ditarik simpulan sebagai berikut: (1) Tidak terdapat pengaruh antara ownership concentration terhadap firm performance; (2) Tidak terdapat pengaruh antara managerial ownership terhadap firm performance; (3) Tidak terdapat pengaruh antara board size terhadap firm performance; (4) Tidak terdapat pengaruh antara CEO family terhadap firm performance; (5) a. Agency cost (asset turnover) berpengaruh positif signifikan terhadap firm performance; $b$. Agency cost (expense ratio) berpengaruh negatif signifikan terhadap firm performance; (6) Firm size berpengaruh positif signifikan terhadapfirm performance; (7) a. Leverage (long term debt to total asset) berpengaruh positif signifikan terhadap firm performance; b. Leverage (long term debt to equity ratio) berpengaruh negatif signifikan terhadap firm performance.

Hasil penelitian ini diharapkan dapat diterapkan oleh perusahaan dan juga investor. Terdapat beberapa implikasi yang terdapat dalam penelitian adalah sebagai berikut:

Pertama. Bagi Perusahaan. Untuk dapat meningkatkan kualitas kinerja perusahaan, ada beberapa faktor yang perlu diperhatikan bagi manajer perusahaan, antara lain : (1) Dilihat dari biaya agensi yang positif jika diukur dengan asset turnover, manajer perusahaan dapat memperbesar biaya agensi untuk mempercepat perputaran aktiva di perusahaan jasa, semakin cepat perputaran aktiva menunjukkan semakin efisien penggunaan keseluruhan aktiva dalam menghasilkan laba dari penjualan. Namun, jika dilihat dari biaya agensi yang negatif jika diukur dengan expense ratio, maka manajer sebaiknya mengontrol biaya-biaya operasional perusahaan, karena semakin besar biaya agensi yang dikeluarkan maka dapat menurunkan kinerja diperusahaan jasa. (2) Dilihat dari pengaruhnya yang positif, membuktikan bahwa semakin besar ukuran perusahaan maka semakin baik kinerjanya, dalam hal ini manajer harus tetap mengelola aset yang tersedia dengan bijak dan perencanaan yang matang, untuk memperoleh keuntungan yang besar, karena semakin besarnya keuntungan maka kinerja di perusahaan akan semakin meningkat. Ukuran perusahaan yang besar tentunya dapat lebih mudah untuk memperoleh pinjaman, namun 
dalam hal ini perusahaan harus tetap menekan tingkat hutangnya. Karena hutang yang besar dapat meningkatkan risiko kebangkrutan jika perusahaan tersebut tidak dapat membayar kewajibannya.

Kedua. Bagi Investor. Sebelum investor melakukan investasi di industri jasa non keuangan, sebaiknya investor memperhatikan agency cost, firm size, dan leverage sehingga investor dapat mengetahui bagaimana keadaan perusahaan dan kinerja perusahaan yang sebenarnya agar investor dapat memperoleh keuntungan yang maksimal dari investasi yang dilakukan.

\section{DAFTAR RUJUKAN}

Al-Ghamdi, Mohammed dan Rhodes, Mark. (2015) "Family Ownership, Corporate Governance and Performance: Evidence from Saudi Arabia". International Journal of Economics and Finance.Vol. 7.No. 2.

Athanassiou, N., Crittenden, W. F., Kelly, L. M., dan Marquez, P. (2006) "Founder Centrality Effects on the Mexican Family Firm's to Management Group: Firm Culture, Strategic Vision and Goals, and Firm Performance". Jurnal of World Business (37), 139-150.

Barberis, Nicholas., Boycko, Maxim dan Shlefer, Andrei dan Vishny, Robert W. (1996) "A Theory of Privatization". Journal of Finance Economics Elsevier.Vol. 35 (2).107-127.

Coles, J .L., Daniel, N.D dan Naveen, L. (2008) “Does One Size Fit All?".Journal of Financial Economics. Vol87.329-356.

Darwis, Herman. (2009) "Corporate Governance Terhadap Kinerja Keuangan”, Jurnal Keuangan dan Perbankan. 13 (3): 418-430.

Demsetz, H. (2013) "The Structure of Ownership and the Theory of the Firm". Journal of Law and Economics. 26 (82): 375-390.

Ehikioya, Benjamin I. (2009) "Corporate Governance Structure and Firm Performance in Developing Economies: Evidence from Nigeria". Journal Corporate Governance. 9 (3): $231-243$.

Fama, E.F. dan Jensen, M.C. (1983) "Separation ofOwnership and Control". Journal of Law and Economics. 26 (2): 301-325.

Forum for Corporate Governance in Indonesia (FCGI). (2001) Seri Tata Kelola Perusahaan (Corporate Governance). (website http://www.fcgi.org, diakses 1 Desember 2015).

Gitman, Lawrence J, and Zutter, Chad J., (2015) Priciples of Managerial Finance. $15^{\text {th }}$ Edition Edinburgh: Pearson.

Hastori., Siregar, Hermanto., Sembel, Roy., Maulana.Tb.N.Ahmad. (2015) "Tata Kelola, Konsentrasi Saham dan Kinerja Perusahaan Agroindustri Indonesia". Jurnal Manajemen Teknologi. 14 (2): 4-8.

Izati, Chaerunisa dan Margaretha, Farah. (2014) "Faktor-Faktor yang Mempengaruhi Kinerja Keuangan Pada Perusahaan Basic Industry and Chemicals di Indonesia". Jurnal Manajemen Fakultas Ekonomi. 1 (2).

Jensen, M.C. (1986) "Agency Costs of Free Cash Flow, Corporate Finance and Take Overs". American Economic Review. 76 (2): 323-329.

Jensen, M.C. (1993) "The Modern Industrial Revolution, Exit and The Failure of Internal Control System". The Journal of Finance. 48: 831-880. 
Jensen, Michael C dan William H. Meckling (1976) "Theory of the Firm: Managerial Behavior, Agency Costs and Capital Structure". Journal of Financial Economics 3.305-360

Lipton, M. dan Lorsch, J.W. (2012) “A Modest Proposal for Improved Corporate Governance". Business Lawyer. 48 (1).59-77.

Margaretha, Farah dan Dhonna, Asmara. (2011) "Pengaruh Konsentrasi Kepemilikan terhadap Kinerja Perusahaan Jasa Go Public". Jurnal Informasi, Perpajakan, Akuntansi dan Keuangan Publik. 6 (1): 45-54.

Memon,F., Bhutta,A., dan Abbas,G. (2010) “Capital Structure and firm's performance: A case of Textile sector Pakistan". Asian Journal of Business and Management Science, 9(1): 9-15.

Miyajima, Hideaki, Yusuke Omi dan Nao Saito. (2008) "Corporate Governance and Performance in Twentienth Century Japan". Bussiness and Economic History. 1 (2): 10-23.

Morck, R., Shleifer, A., dan Vishny, R. (1988) "Management Ownership and Market Valuation: An Empirical Analysis". Journal of Financial Economics, 20 (1): 293315.

Organization for Economic Cooperation and Development (OECD). (2004) OECD Principles of Corporate Governance 2008. The OECD Paris.

Sari, Amelia Chrisnata. (2015) "Pengaruh Mekanisme Corporate Governance terhadap Kinerja Perusahaan pada Sektor Consumer Goods Industry di BEI Periode 2009-2013”. Jurnal Ilmiah Mahasiswa Universitas Surabaya. Vol 4. No.2.

Sari, Derry Permata dan Usman, Bahtiar. (2014) "Pengaruh Board Structure dan Ownership Structure terhadap Firm Performance pada Perusahaan Manufakur yang Terdaftar di Bursa Efek Indonesia". e-Journal Manajemen. 1 (2): 44-69.

Setyapurnama, Yudi Santara dan A.M Vianey Norpratiwi. (2006) "Pengaruh Corporate Governance Terhadap Peringkat Obligasi dan Yield Obligasi". Jurnal Riset Akuntansi Indonesia, 9:1-28.

Shinduja, P. (2009) "Performance and Value Creation: Family Managed Business Versus Non-Family Managed Business". The IUP Journal of Business Strategy. 6 (3): 6680.

Shleifer, A., dan Vishny, R. W. (2006) "Large Shareholders and Corporate Control". Journal of Political Economy. 94 (3): 461-488.

Wahidahwati. (2012) "Pengaruh Kepemilikan Manajerial dan Kepemilikan Institusional pada Kebijakan Hutang Perusahaan: Sebuah Perspektif Theory Agency". Jurnal Riset Akuntansi Indonesia. 5 (1): 601-614.

Wright, Peter., Mark Kroll, Ananda Mukhreji, Michael L. Pettus. (2009) "Do the Contingencies of External Monitoring, Ownership Incentives, or Free Cash Flow Explain Opposing Firm Performance Expectations?", Journal Management Governance, 13: 215-243.

29.Yermack, D. (2006) "Higher Market Valuation of Companies with a Small Board of Directors". Journal of Financial Economics. 40: 185-21. 